\title{
Guest Editorial: Perspectives on Megaprojects
}

\author{
Willie Tan \\ Department of Building, National University of Singapore
}

\section{Introduction}

This special section on megaprojects raises the issue on how megaprojects should be conceptualized and studied. What exactly is a megaproject, and from what perspectives should it be examined? This question is not trivial; unless one is able to identify the properties of a megaproject as an object of study, it is hard to know where to start thinking about such projects.

\section{Early studies}

Most project managers regard ancient projects such as the pyramids and Great Wall as megaprojects. The modern history of megaprojects is relatively recent, and may be dated from the construction of turnpikes and railway manias of the 19th century (Lewin, 1968; Wood and Karr, 1997). Comprehensive river basin development, such as the Tennessee Valley development of the 1930s (Downs, 2014), is also an example of a megaproject. The term "mega" (million) was subsequently popularized by the computer industry in the 1950s when hard disk storage capacity of a few megabytes appeared.

In the 1960s, the term "megaproject" was also used to refer to an integrated rural development programme comprising a set of projects such as a road, market, irrigation, housing, school, and hospital (e.g. Kahn, 1965). The focus is on the coordination and integration of different projects to serve rural communities.

A study by Rand Corporation (Merrow, 1988) defined megaprojects as costing US\$1 bn and above. The figure is clearly arbitrary, but a number of traits beyond capital outlay and coordination were identified, such as its long duration, political visibility, significant community, economic, and environmental impacts, regulatory difficulties, numerous stakeholders, and huge resource requirements. However, it was actual capital outlay that allowed the easy identification of specific megaprojects for further study, such as cost growth and schedule slippage.

Clearly, a long list of unordered properties of megaprojects is not helpful and there is much to disagree on the items in the list as well as their relative importance in determining project outcomes.

\section{Risks}

A second group of studies focuses on risks as the defining feature of megaprojects. For instance, Greiman's (2013) account of the Big Dig project in Boston is intended to draw lessons on risk and project management. A standard risk management framework or process comprising risk identification, assessment, mitigation, monitoring, and review was used.

Copyright: Construction Economics and Building 2015. (C) 2015 Willie Tan. This is an Open Access article distributed under the terms of the Creative Commons Attribution 4.0 Unported (CC BY 4.0) License (https://creativecommons.org/licenses/by/4.0/), allowing third parties to copy and redistribute the material in any medium or format and to remix, transform, and build upon the material for any purpose, even commercially, provided the original work is properly cited and states its license.

Citation: Tan, W. 2015. Guest editorial: perspectives on megaprojects, Construction Economics and Building, 15(3), 1-3. DOI: http://dx.doi.org/10.5130/AJCEB.v15i3.4602

Corresponding author: Willie Tan; Email - willietan@nus.edu.sg

Publisher: University of Technology Sydney (UTS) ePress 
In contrast, other researchers are more specific about the kinds of risks they wish to investigate. For example, Miller and Lessard (2000) argued that the presence of coherent and well-developed institutional arrangements is the key determinant of project performance. Similarly, Flyvbjerg, Bruzelius and Rothengatter (2003) raised the old issue of why project costs tend to be underestimated (see Waterston (1965) for an early account of this) and, more generally, the lack of accountability in public projects. Fox and Miller (2006) took an entirely different path, focusing on the first-of-its-kind megaprojects where there is little information and few guidelines for planning and execution.

Another possibility is to emphasize the project constraints of time, cost, quality, safety, and good relations (e.g. Tan, 2007). In this perspective, megaprojects are particularly vulnerable to time and cost overruns because of the long duration and large capital outlay. Here, the emphasis is on the higher probability of the impact of external events such as interest rate hikes and regulatory changes.

Many studies of megaprojects, including those included in this issue, fall into this category. The general strategy is to identify a particular risk or a set of risks and then examine ways to manage them. A caveat should be added: the results of most studies cannot be generalized because they are based on a small sample of projects.

\section{Complexity}

A third group of studies focuses on complexity or chaos theory (e.g. Remington and Pollack, 2007; Williams, 2001), and generally as part of systems theory. The basic concepts include interactions, adaptive behaviour, emergent properties, and non-linearity. Unlike the standard reductionist approach where the project output is broken down into smaller components, the emphasis in complexity theory is interactions between the parts, and hence possible emergent properties in nonlinear systems.

It is important to note that the term "complex" is often used loosely to refer to projects that are difficult to manage, or technically complicated. If the key concepts of complexity theory outlined above are not used, then the project can be complicated, but certainly not complex in the sense of applying chaos theory. A complicated project is certainly challenging, but it does not have the properties of complexity.

In the 1970s, economists were keen to apply complexity theory to the study of business cycles (Varian, 1979; Zeeman, 1974) but there were doubts about its usefulness (Guckenheimer, 1978). In project management, complexity theory continues to be a marginal movement with potential for further development.

\section{Conflict}

A fourth group of studies focuses on power and conflict (e.g. Altshuler and Luberoff, 2003; Plotch, 2015). It is similar to the "urban growth machines" and "urban regimes" studies of the 1980s (Logan and Molotch, 1988; Stone, 1989) where the city's growth coalition of politicians, bureaucrats, businesses, and other groups orchestrated urban renewal strategies in response to fiscal stress and declining federal assistance for American cities.

For megaprojects, the stakes are high because the projects are costly and risky. Hence the "machines" or "political regimes" need to promote a growth ideology as well as overcome resistance in implementing large infrastructure projects. Conflict may be pervasive, and not everyone is progrowth. There will be winners and losers. The focus, then, is on the external environment rather than internal stakeholders of the project. 
Not everything is about business, politics, and projects. One form of resistance is through discourse, such as through the history of debates in environmentalism to save the forests (e.g. Chase, 2001). In some cases, the megaproject is transnational (e.g. a pipeline or rail project), bringing in a new set of resistance beyond the usual class, race, gender, religion, and the environment.

\section{Humanism}

A final perspective is humanistic, focusing on human experience in megaprojects. An early perspective is Jacobs' (1961) critique of urban planning, particularly highways, roads, and segregated suburban land uses that caused the "death" of American cities. Similar critiques may be found in attempts to re-humanize the massive architecture of megaprojects (Holston, 1989). These studies focus on humanistic small-scale solutions in massive projects, or to replace them altogether.

Beyond architecture, it is possible to study the experiences of people directly affected by megaprojects. Jamali's (2013) work on the experience of anxiety among local fishermen in Gwadar (Pakistan) in the wake of the construction of the Gwadar Deep Water Port Project (2002-7) is an example. Here, fortunes of these families rose and ebbed like the tides. While the megaproject brought hope and promise, the subsequent collapse of the real estate bubble and armed resistance by Baloch nationalist insurgents ushered in despair.

\section{References}

Altshuler, A and Luberoff, D., 2003. Megaprojects: The changing politics of urban public investment. DC: Brookings Institution Press.

Chase, A., 2001. In a dark wood: The fight over forests and the myths of nature. New York: Transaction Publishers.

Downs, M., 2014. Transforming the South: Federal development in the Tennessee Valley, 1915-60. Baton Rouge: Louisiana State University Press.

Flyvbjerg, B., Bruzelius, N and Rothengatter, W., 2003. Megaprojects and risk: An anatomy of ambition. London: Cambridge University Press. doi: http://dx.doi.org/10.1017/cbo9781107050891

Fox, R. and Miller, D. 2006. Challenges in managing large projects. Virginia: Defence Acquisition University Press.

Guckenheimer, J., 1978. The catastrophe controversy. Mathematical Intelligencer, 1, pp.15-20. doi: http://dx.doi.org/10.1007/BF03023037

Greiman, V., 2013. Megaproject management. New York :Wiley. doi: http://dx.doi.org/10.1002/9781118671092

Holston, J., 1989. The modernist city: An anthropological critique of Brasilia. Chicago: Chicago University Press.

Jacobs, J., 1961. The life and death of Great American cities. New York: Random House.

Jamali, H., 2013. The anxiety of development: Megaprojects and the politics of place in Gwadar, Pakistan. Bonn: Crossroads Asia Working Paper Series No. 6.

Kahn, A., 1965. Comilla district integrated rural development programme. Comilla: Pakistan Academy for Rural Development.

Lewin, H., 1968. Railway mania and its aftermath, 1845-52. London: David \& Charles.

Logan, J. and Molotch, H., 1988. Urban fortunes: The political economy of place. California: University of California Press.

Merrow, E., 1988. Understanding the outcomes of megaprojects (R-3560-PSSP). California: Rand Corporation.

Miller, R. and Lessard, D., 2000. The strategic management of large engineering projects. Cambridge: MIT Press.

Plotch, P., 2015. Politics across the Hudson: The Tappan Zee megaproject. New Jersey: Rutgers University Press.

Remington, K. and Pollack, J., 2007. Tools for complex projects. Surrey: Gower.

Stone, C., 1989. Regime politics. Lawrence: Kansas University Press.

Tan, W., 2007. Principles of project and infrastructure finance. London: Taylor and Francis.

Varian, H., 1979. Catastrophe theory and the business cycle. Economic Inquiry, 17(1), pp.14-28. doi: http://dx.doi.org/10.1111/j.1465-7295.1979.tb00293.x

Waterston, A., 1965. Development planning. Baltimore: Johns Hopkins Press.

Williams, T., 2001. Modelling complex projects. New York: Wiley.

Wood, F. and Karr, R., 1997. The turnpikes of New England. Massachusetts: Branch Line Press.

Zeeman, C., 1974. On the unstable behaviour of the stock exchanges. Journal of Mathematical Economics, 1(1), pp.39-44. doi: http://dx.doi.org/10.1016/0304-4068(74)90034-2 